\title{
Service-Dominant Logic and Service Logic - Contradictory and/or Complementary? AUTHOR VERSION
}

Saarijärvi, H., Puustinen, P., Yrjölä, M., \& Mäenpää, K. (2017). Service-dominant logic and service logic-contradictory and/or complementary? International Journal of Services Sciences, 6(1), 1-25.

\section{Abstract}

In the contemporary marketing theoretical discussion there has been a widely established effort to revitalize the concept of service. In this endeavour, conceptual friction between two well-established marketing theoretical logics, namely Service-Dominant logic (S-D logic) and service logic has emerged. Although these perspectives have been widely debated, there have not been systematic efforts to analyse their conceptual differences. Analysing these differences will aid the further development toward more consistent marketing theory. Thus, this study identifies areas of contradiction and complementarity between S-D logic and service logic. 


\section{Introduction}

Recent developments within the field of marketing theory have given a sense of direction to a discipline that has long been fragmented into a variety of subsidiary areas of study. Contemporary academic discussion around different service perspectives has prompted the need to make sense of the discipline as a whole, and has ranged over a substantial portion of the history of marketing thought. In general, there has been a widely established effort to revitalize the concept of service and upgrade the discussion to a new level. Today, service is not conceptualized as it was when services marketing evolved as a subdiscipline (see Berry and Parasuraman, 1993; Fisk et al., 1993). Contemporary discussion around service has shifted towards concepts such as value co-creation, value-in-use and interaction, not only in B2C but also in B2B contexts (e.g. Zacharia et al., 2011). These evolving servicerelated concepts have been widely debated by the academic research community, developed further, and as a result, they not only form the very foundation of contemporary service theory, but also play a critical role in broader marketing theory. Service perspectives such as service-dominant logic (S-D logic) (e.g. Vargo and Lusch, 2004a, 2008a; Lusch, 2007; Lusch and Vargo, 2006a; Vargo, 2007a, 2007b), service logic (e.g. Grönroos, 2005; Grönroos, 2008a, 2008b, 2011a, 2011b), service science (e.g. Maglio and Spohrer, 2008; Maglio et al., 2009), as well as many-to-many marketing (e.g. Gummesson, 2008), customer-dominant logic (e.g. Heinonen et al., 2013; Heinonen et al., 2010; Heinonen et al., 2009) and the viable system approach (e.g. Barile and Polese, 2010; Badinelli et al., 2012) have intensively addressed, refined and adjusted the nature and characteristics of these concepts, and consequently attracted a great deal of interest from scholars and practitioners ever since the seminal article by Vargo and Lusch (2004a). More recently, others have called for theoretical discussion to be linked with empirical findings through midrange theories (e.g. Brodie et al., 2011), for evolving service perspectives to be connected to other well- 
established theoretical perspectives, such as Consumer Culture Theory (e.g. Peñaloza and Mish, 2011), and for scholars to continue to explore their full potential to contribute to a metatheory (e.g. Löbler, 2011). Together these approaches have resulted in numerous journal articles and special issues, books and conference papers that collectively seek to redefine the role of service within marketing theory and society in general.

Recently, there has been some friction evident in scholarly discussions on the two well-established service perspectives, S-D logic and service logic. The discussion has resulted in both differing and overlapping approaches to the basic building blocks of contemporary service theory as well as the general focus of marketing. For example, S-D logic considers service exchange as the fundamental construct in marketing (Vargo and Lusch, 2008b), whereas service logic identifies interaction as performing that role (Grönroos, 2008a). Although the differences may to some extent seem marginal or merely semantic, in order to enhance the understanding of marketing theory and, more importantly, develop it further, it is still very important to be aware of them and their origins. Without systematic and detailed conceptual analysis there is a danger that the concepts gradually morph into one, even though they are fundamentally intended to capture different aspects of the service phenomenon. Nevertheless, despite the intensive and wide scholarly interest, the extent to which these perspectives overlap or differ remains somewhat unclear.

The existing literature has not systematically analysed their conceptual differences in detail, which has resulted in confused interpretations by scholars of how the perspectives interrelate, and has caused friction in the development of a more coherent and consistent theory, and as Ballantyne et al. (2011) point out, the definitional and conceptual problems remain unclear. To address this knowledge gap, this study identifies the differences between S-D logic and service logic. As a result, the study elaborates on the contradictory and/or complementary conceptual characteristics of the respective service perspectives. 
Furthermore, the study provides a synthesized and summarized source of reference to the vast contemporary service literature surrounding the marketing field, and so will help scholars exploring the topic to familiarize themselves with the increasingly important service domain.

The study is organized as follows. First, its research methodology is briefly discussed in terms of how the literature review was assembled and the results analysed. Second, the results are presented in the form of eight key concepts identified during the analysis process. Here the contradictory and/or complementary characteristics of the service perspectives are also discussed. Finally, the study offers its conclusions and sets out future research challenges and opportunities.

\section{Methodology}

When designing the appropriate set of search criteria to identify suitable articles for addressing the differences between S-D logic and service logic, two fundamental clarifications related to the study positioning. First of all, since the introduction of S-D logic (Vargo and Lusch, 2004a), other independent or partly parallel service-related literature streams have been identified. These include, for example, service science, many-to-many marketing, customer-dominant logic and the viable systems approach. Service logic is largely based on the Nordic School research tradition, but in recent years has gradually evolved into a service perspective with its own conceptual foundation. Although these literature streams share many similar characteristics, they have still developed separate identities. When conducting a conceptual comparison, it is thus of the greatest importance to be aware of the different literature streams and base the comparison on the contributions of such authors that represent the chosen literature streams while excluding the influence of other scholarly domains (see Figure 1). Consequently, in the scope of this study, the focus 
was particularly on how the two service perspectives, S-D logic and service logic, differ in relation to each other. In that respect, Figure 1 is not intended to offer an all-encompassing summary of the recent service-related scholarly evolution, but through some key articles provide a rough illustration of the inter-linkages, evolution and conceptual positioning of the different service-related literature streams. Nor do the lines between different articles in the respective service-related perspectives illustrate their developments in objective terms, but are rather intended to help understand their conceptual positioning in relation to S-D logic and service logic. For example, as depicted in Figure 1, service science, viable systems approach and many-to-many marketing have adopted a somewhat more macro perspective. This does not in any way mean that they exclude micro level analysis - quite the contrary simply that they now largely operate on a more macro level of analysis. Consequently, focusing on S-D logic and service logic is not just about choosing two service perspectives for a detailed exploration per se, but concerns identifying two well-established service perspectives that are located at quite opposite ends of the macro and micro continuums, and instigating a conceptual analysis of them. The figure also helps position the study and explicitly defines the time frame that bounded the literature review.

\section{"Insert Figure 1 approximately here"}

Second, while S-D logic is considered an open source project and Vargo and Lusch have repeatedly welcomed scholars to contribute to its development, at the conceptual level, the roles of Vargo and Lusch cannot be underestimated. At least during the first decade of the S-D logic, it is largely their insights and opinions that qualify the conceptual development of the S-D logic domain. In that respect, and given the vast number of different scholars and the wide variety of articles related to S-D logic published across the global scholarly 
community, the literature review was limited to contributions by Vargo and/or Lusch. Despite this limitation, the search produced a large number of articles that adequately capture the conceptual evolution of S-D logic. Similarly, as the focus was on service logic, not on the Nordic School tradition characterized by renowned service scholars such as Evert Gummesson and Bo Edvardsson, the search was limited to those articles (co-)authored by Grönroos.

In the actual literature review, two criteria were applied to the selection of the final set of articles. In line with the justification offered above, the search was first limited to peer-reviewed journal articles authored by Vargo and/or Lusch on S-D logic and by Grönroos on service logic. Second, in acknowledgement of the seminal article by Vargo and Lusch (2004a) being the catalyst for theoretical evolution, the search was limited to research published between 2004 and 2013. Articles that were only electronically accessible at the end of 2012 but were about to be published in 2013 were also included in the literature review (e.g. Grönroos and Voima, 2013). Given the diverse nature and context of both S-D logic and service logic, the studies that have contributed to their domains are not restricted to marketing journals only but emanate from a number of journals in various disciplines including, for example, European Management Journal, Organizational Dynamics, the Journal of Supply Chain Management, and the Journal of Retailing, which necessitated extending the search from marketing to other applicable areas of research. Well-known online journal databases (ABI/Inform, EBSCO Business Source Premier, and Emerald FullText) were used in the search for appropriate articles. The search was complemented by a manual search focusing on the authors' homepages and bibliographies (e.g. http://www.sdlogic.net). The search produced 84 journal articles (see Table 1).

“Insert Table 1 approximately here" 
Seven articles by Vargo and/or Lusch and three by Grönroos were excluded from the final set as they were adjudged not to contribute to the subject of this study. Each decision to exclude an article made by the authors was unanimous. (See Table 2).

\section{"Insert Table 2 approximately here"}

The articles identified as suitable for the literature review were carefully read by the authors and their content analysed in terms of their conceptual contribution. The literature review provided a systematic, thorough and analytical way to uncover and explore the basic concepts of both S-D logic and service logic. In order to make the coding process transparent and acknowledge the importance of expert judgements to correct concept categorization, the authors individually evaluated the possible concepts. During this process, the authors paid attention to the validity of the concepts and whether they were representative, comprehensible, and unambiguous. The results of the concept categorization were then discussed between the authors. The discussion resulted in ten central concepts. Many of the concepts were reworded to take the range of authors' comments into account. Thus the variation concerning the categorization (e.g. Value + Value-in-use $=$ Nature of Value) were resolved by discussion between the authors. As a result of this procedure, two content-analysed concept categories, namely Marketing focus and Value co-production were removed from further analysis. Marketing focus was dropped as it provides an inner-perspective to marketing as a discipline, rather than being a defining concept. Value co-production in turn was embedded in the concept of value co-creation. Finally, eight concepts were chosen following the authors identifying, discussing, and reflecting the conceptual contributions within and between the service perspectives. The 
authors regard the concepts to be central constructs of both service perspectives during the study period (2004-2013), and to offer a good starting point for a study of the conceptual differences between those service perspectives; they provided the lens through which to address the research purpose.

The actual analysis was then divided into two phases. First, where possible, the evolution of the concepts within the service perspectives was discussed. Two main questions drove the analysis: how the concepts differed between the perspectives, and why (see Figure 2). Second, using the latest contributions available, the actual differences between the perspectives were identified. These concepts are next discussed in more detail.

\section{Identifying contradictions and complementarities between S-D logic and service logic}

\section{Goods}

Both S-D logic and service logic strongly challenge the traditional goods-centred view where goods are perceived as being embedded with value and customers as eventually destroying value. To challenge this, in their seminal article on S-D logic, Vargo and Lusch (2004a) argued that goods are transmitters of service. This argument by Vargo and Lusch (2004a) is based on the well-known means-end-chain approach (Gutman, 1982) that was developed as a way to understand cognitive structures in relation to decision-making and engagement in experiences. Gutman suggests the means-end approach provides a basis for understanding the cognitive linkages between specific situational knowledge (attributes and consequences) and self-knowledge (consequences and values). In this context, attributes can be considered concrete and tangible characteristics of a product, whereas benefits or consequences refer to what the product does or provides to the consumer at the functional 
or psychosocial level. Values are then considered as intangible, higher-order ends that reflect the most basic, fundamental needs of the consumer (Vriens and ter Hofstede, 2000).

Following Vargo et al. (2008; see also Schmenner et al., 2009) goods are intermediate products that are used as appliances in the value creation process; in other words, the role of goods is to act as a vehicle for operant resources enabling access to the benefits of an organization's competences. Naturally, customers also need to learn, use, maintain, repair and adapt the goods to their needs in order to realize their value (Vargo and Lusch, 2008a).

More recently, the focus has moved towards perceiving goods as enablers of service provision rather than as of primary importance to exchange or value creation (see Vargo, 2009). Goods are vehicles or distribution mechanisms for service provision (Lusch and Vargo, 2009; Vargo and Akaka, 2009) and they derive value from usage, that is, from the service they provide (Lusch and Vargo, 2009). Service is superordinate to goods: 'when one purchases a tangible good it is with the intent of using that good in a particular context to provide a service to oneself (i.e., self-service) or another' (Lusch and Vargo, 2009, p. 8).

Service logic, in turn, defines goods as value-supporting resources; that is, as an input resource for customers' value creation: 'goods are resources like other physical objects such as credit cards and airline seats: the firm makes them available for money so that customers in their own processes will be able to use them in a way that creates value for them, as individuals, households or organizations' (Grönroos, 2006a, p. 323). Thus, service logic addresses goods as resources supporting the customer's value creation. Goods cannot transmit service alone, nor do goods as such render services, nor does the customer use them as services; other resources, such as information, are needed as well. In that respect, goods that are not provided within a service process enable a self-service process 
in the customer's sphere; a good represents only potential value for the consumer (Grönroos, 2011a, 2011b).

\section{Service}

In general, S-D logic and service logic see the shift in focus from goods to service as a prerequisite for developing marketing theory. Numerous articles assert that marketing has been based on false assumptions, for example, about the nature of value (e.g. Vargo and Lusch, 2004a; see also Vargo and Lusch, 2004b, 2008c). Marketing's focus should not be on goods or services, but on service and the customer's context. Originally, S-D logic defined service as the application of specialized competences (knowledge and skills) through deeds, processes, and performances for the benefit of another entity or the entity itself' (Vargo and Lusch, 2004a, p. 2), and thus underlined the importance of intangibility. To that end, service is expressed as the singular ("service") rather than as a conceptualization of an intangible unit of output ("services") (see e.g. Vargo and Lusch, 2008a). The primary focus should shift beyond goods and services towards benefit. More recently, the S-D logic approach to service has been influenced by the discussion around service science, originally an IBM-led discipline that focused on the interdisciplinary study of service systems (Maglio et al., 2009). Service science was initiated independently from S-D logic, but it was soon evident that they shared similar characteristics; it was even argued that its theoretical basis is S-D logic (Maglio and Spohrer, 2008), although S-D logic is not considered a theory (e.g. Vargo, 2007a). Consequently, S-D logic does not only provide a micro perspective, but has adopted both a somewhat macro and systemic perspective on service and value creation, as described by Maglio et al. (2009, p. 403; see also Vargo, 2011c): 'Service is the application of resources (including competence, skills, and knowledge) to make changes that have value for another (system)'. 
More recently, Lusch and Vargo (2011, p. 1303) have addressed both means (activities) and ends (functions) as important elements of service, referring to the well-known means-ends approach: 'products are "means" for reaching "end-states", or "valued states of being" such as happiness, security and accomplishment'. In summary, in S-D logic, 'service is defined as applied operant resources (knowledge and skills) for the benefit of another or oneself (self-service)' (Lusch and Vargo, 2011, p. 1306; see also Lusch and Vargo, 2012).

Just as goods were defined as value-supporting resources, so service logic views service as a value-supporting process (Grönroos, 2006a; 2008a). Service is 'a process that consists of a set of activities which take place in interactions between a customer and people, goods and other physical resources, systems and/or infrastructures representing the service provider and possibly involving other customers, which aims at assisting the customer's everyday practices' (Grönroos, 2008a, p. 300). To that end, service is the process of different resources, including goods, functioning together (Grönroos, 2006a); service is the mediating factor in the process of reciprocal value creation for both the customer and the supplier respectively (Grönroos and Ravald, 2009). In this sense, all firms are service businesses (Grönroos, 2009). While not disagreeing with this notion, S-D logic extends it by stating that not only are all businesses service businesses, but all economies are service economies (Vargo and Morgan, 2005).

More recently, Grönroos has emphasized the distinction between customer service logic and provider service logic (e.g. Grönroos, 2011a). The former relates to customers combining the resources provided by the firm with other resources in their everyday practices. The latter, in turn, adopts the perspective of the firm, arguing that through interactions with customers firms can develop opportunities for value co-creation. In these cases, service can be understood as value-creating support for the customers' processes (Grönroos, 2008a, 2011a). Consequently, provider service logic is a business logic based 
on service provision (Grönroos, 2011a). It refers to a supplier providing support to its customers' business processes (see Grönroos and Helle, 2012). This is achieved 'through value-supporting ways of assisting the customers' practices relevant to their business (business effectiveness instead of operational efficiency only)' (Grönroos, 2011a, p. 241; see also Grönroos and Helle, 2012). Thus, in a business context, what is considered a "practice" is a process or an activity that is performed by the customer or the supplier (Grönroos and Helle, 2012). Service logic sees service both as the fundamental basis of business and as a logic of value creation (Grönroos, 2011a). In this respect, too, all firms are service businesses (Grönroos, 2009).

\section{Nature of value}

S-D logic stresses that value emerges in the customer's consumption context: 'value results from the beneficial application of operant resources sometimes transmitted through operand resources' (Vargo and Lusch, 2004a, p. 7). Value can be perceived as being a result of the provider's and consumer's actions, but is always defined by the consumer (Vargo and Lusch, 2006, p. 44). More recently, S-D logic has stressed the importance of using the terms beneficiary or actor instead of customer, which extends the discussion beyond a B2C context to an actor-to-actor level of abstraction. Lusch and Vargo (2012) argue that the distinctions between producers and consumers or firms and customers constrain the description of markets and marketing; all social and economic actors are ultimately generic actors that are resource-integrating, service provisioning, and value co-creating.

Consequently, 'value is always uniquely and phenomenologically determined by the beneficiary' (Vargo and Lusch, 2008a, p. 9). In other words, in contrast to the well established and widely communicated service-related IHIP construct, value is always 
intangible, heterogeneously experienced, co-created, and potentially perishable (Vargo and Lusch, 2008b). However, before value is actualized, the customer must adapt to using the offering (see Vargo and Lusch, 2008a). Input resources provided by the firm 'must be integrated with other resources, some of which are also obtained through the market and some of which are privately (e.g. personal, friends, family) or publically (e.g. government) provided' (Vargo and Lusch, 2010c, p. 172; see also McColl-Kennedy et al., 2012). Consequently, it is during the use of the firm's offering when true value is actualized and not when money is exchanged for the offering (Lusch and Vargo, 2009). In that respect, customer value can been seen as an unfolding process, as suggested by Vargo (2009, p. 375): 'This unfolding, co-creational (direct or through goods) nature of value is relational in the sense that the (extended) activities of both parties (as well as those of other parties) interactively and interdependently combine, over time, to create value'.

According to S-D logic, this phenomenological nature of customer value suggests that value is 'idiosyncratic, experiential, contextual and meaning laden' (Lusch and Vargo, 2011, p. 1304), which puts pressure on employing a multiple-perspective view of the nature of value. S-D logic has therefore gradually adopted a system approach to value creation by emphasizing the actions of the network actors as necessary contributors to the (co-)creation of value (see Vargo and Lusch, 2011; see also Gummesson et al., 2010; Chen and Vargo, 2010). Hence, S-D logic views value creation from a wider perspective than is typical : 'It brings into view not only focal actors - the focal service provider (e.g., firm) and beneficiary (e.g., customer) - but also the context - the networks of resources and resource-providing actors - available to these actors' (Vargo and Lusch, 2011a, p. 183). Consequently, in contrast to the traditional, dyadic firm-customer interaction, S-D logic adopts an extended venue for value creation by emphasizing that neither the firm nor the customer alone possesses sufficient resources for value creation (Vargo and Akaka, 2009). Through its 
close connection with the service science perspective (see e.g. Vargo et al., 2008), value is thus considered as an improvement on a system, 'as determined by the system or by the system's ability to adapt to an environment' (Maglio et al., 2009, p. 403). Due to its extended view, S-D logic has further emphasized the role of context in value creation, and shifted the focus from value-in-use towards value-in-context (see e.g. Chandler and Vargo, 2011), or even value-in-cultural-context (Akaka, Schau and Vargo, 2013). Context is a critical determinant of value (Lusch and Vargo, 2009; see also Vargo and Akaka, 2009). It emphasizes time and place dimensions and network relationships as the most important variables in both the creation and determination of value; 'value-in-context is uniquely derived at a given place and time and is phenomenologically determined based on existing resources, accessibility to other integratable resources and circumstances' (Vargo and Akaka, 2009, p. 39). Thus, resources become resources due to the context they are embedded in (Chandler and Vargo, 2011). Context is an important dimension of value cocreation as 'it frames exchange, service, and the potentiality of resources from the unique perspective of each actor, and from the unique omniscient perspective of the entire service ecosystem' (Chandler and Vargo, 2011, p. 45).

Both S-D logic and service logic view value as something that is defined by the customer or beneficiary and recognize the processual nature of value creation, which in service logic is also referred to as customer service logic (Grönroos, 2008a; 2011). Provider service logic, in turn, is about the firm developing opportunities for value co-creation through establishing interactions. Consequently, service logic adopts a more micro level approach by investigating value creation within a dyadic relationship between customer and firm, whereas S-D logic prefers a network and systemic approach to the nature of value and value creation. Service logic views customers' creation of value-in-use as emerging in the customer sphere and from everyday activities: 'Value accumulates throughout the 
customer's value-creating process' (Grönroos and Voima, 2013, p. 146; see also Grönroos, 2011b). Value-in-use is a function of value-in-exchange (Grönroos and Helle, 2010). Thus, service logic does not neglect the value-in-use concept. According to service logic (see Grönroos and Ravald, 2011), value creation is a dynamic process and can be captured with the value-in-use concept, whereas value-in-context implies a somewhat static approach.

Furthermore, service logic opposes the notion of S-D logic that value is always cocreated, by stating that value creation should not be regarded as an all-encompassing process (Grönroos, 2011b). It is the customer 'who constructs and experiences value by integrating resources / processes / outcomes in his or her own social context' (Grönroos and Voima, 2013, p. 6). Value creation is a process where the customer as user is in charge (Grönroos, 2011b), and 'value for customers means that after they have been assisted by a self-service process or a service process they are or feel better off than before' (Grönroos, 2008a, p. 305). Hence, the customer is the sole creator of value rather than a co-creator of value. Value co-creation, in contrast, is a joint process that requires interaction and the presence of both the customer and the supplier. Value creation (or creation of value-in-use) is characterized by being located within the customer's context or user's sphere and, in that respect, it is the supplier that is eventually invited to engage with the customer's processes and not vice versa. Overall, Grönroos (2011b) suggests that making a conceptual distinction between value generation as the process leading to value-in-use and value creation as the customer's creation of value-in-use will contribute to a better understanding of the value creation phenomenon as a whole.

Value proposition 
Conceptually, S-D logic and service logic agree on the basic characteristic of a value proposition; that it is a promise about the nature of value-in-use that the customer is able to create using the firm's offering. The more far-reaching implications, however, differ according to the service perspective adopted. The S-D logic holds that firms can only offer value propositions which is well established in the seventh foundation premise of Vargo and Lusch (2008a). To that end, in terms of competitive advantage, as firms can only offer value propositions, they can position themselves in relation to competitors only on the basis of collaboratively developed value propositions. Naturally, the value propositions ought to be more compelling than those developed by competitors (Lusch et al., 2007; Lusch et al., 2008). Normatively, firms should focus on value propositions that utilize the firm's resources 'for specific kinds of human problems, needs, desires, and solutions rather than making things' (Vargo and Lusch, 2008b, p. 34). Then, if the customer accepts the value proposition, value can be created jointly (Lusch et al., 2006).

Service logic approaches value propositions as 'suggested value that has not been realized yet' (Grönroos, 2009, p. 353); a value proposition must be regarded as a promise that customers can eventually extract some value from the firm's offering (Grönroos and Voima, 2013). Service logic agrees that, in cases where no interaction is present and the firm is unable to gain access to the process where value-in-use is being actualized, the firm can only offer value propositions: 'A supplier providing goods only without engaging itself with its customers' processes can make value propositions only or only suggest what value the customers should be able to create out of the resources they buy' (Grönroos, 2009, p. 353). However, firms can develop ways to influence not only the design of the value proposition but also the process of value actualization (Grönroos, 2008a). By being actively involved in the customer's value creation process a firm can also influence the value-in-use, that is, the service provider can go beyond making value propositions alone (Grönroos and 
Voima, 2013). This is achieved through establishing interactions between the firm and its customers, which can create new opportunities for developing 'marketing beyond promisemaking activities' (Grönroos, 2011b, p. 295).

\section{Customers}

S-D logic views the customer, or beneficiary, as a co-creator of value. When a customer uses a product, he or she continues 'the marketing, consumption and value-creation and delivery process' (Vargo and Lusch, 2004a, p. 11) and is part of the extended enterprise (Lusch and Vargo, 2009). The customer is seen as an operant resource, rather than operand resource (see Merz et al., 2009), and consequently as a collaborative partner promoting the market with philosophy (Lusch et al., 2007, p. 6) and as an active participant in the value creation process.

Service logic, however, defines the customer as the sole creator of value. Both the firm and the customer are required to have value foundations before value potential can be developed into value-in-use (Grönroos, 2008a). According to Grönroos (2011b), the notion that the customer is always a co-creator of value is too simplistic to support theory development and practical decision making. As mentioned earlier, only in some cases, when the firm establishes an interaction with the customer's value-creating processes, can the firm act as a co-creator of value. In the customer's independent value creation process, the only interaction is with physical, virtual, mental or imaginary resources obtained from the firm (Grönroos and Voima, 2013).

\section{Firms}

According to S-D logic, firms exist in order to integrate and transform different kinds of microspecialized competences into services (Vargo and Lusch, 2006). Normatively, firms should 
enhance the long-term well-being of their customers by developing relationships and providing information and exchange processes that are transparent and symmetrical. Both employees and customers should be recognized as valuable operant resources that each affect the value creation process. Goods are only a mechanism for service provision; the fundamental objective of the firm is to focus on service flow. As described by Lusch et al. (2006, p. 269), 'S-D logic encourages firms and their customers to think in terms of these service flows, rather than in terms of purchasing goods'. Thus, the firm's role is to propose and co-create value and provide service (Vargo et al., 2008) by offering 'input for the customer's resource-integrating, value-creation activities' (Vargo, 2008, p. 214). In that respect, as suggested by Merz et al. (2009, p. 330), 'whereas G-D logic [Goods-Dominant logic] views the "producer" as the creator of value and the "consumer" as a user (and destroyer) of value, S-D logic views both as "resource integrators" (FP9) that co-create value (FP6)'. The firm and the customer are not considered separately but rather as an integrated entity and economic system (Lusch and Vargo, 2009). As Chandler and Vargo (2011, p. 46) state: 'Most useful in this framework is the absence of the dichotomy between firms and their 'customers', which is replaced with a collective conceptualization of actor based on resources, service efforts, and contexts' (see also Vargo and Lusch, 2011a).

Service logic views firms as providing customers with a value foundation. When customers add other resources and skills, the value potential of that value foundation is converted into value-in-use (Grönroos, 2008a). Instead of considering whether offerings are goods or services, firms should focus on understanding customers' everyday practices and value-creating processes where both goods and services are consumed jointly. Therefore, a firm's most important role is to facilitate its customers' own processes (Grönroos, 2008a): '... suppliers do not deliver value to customers, they support customers' value creation in value-generating processes of these customers, and possibly get involved in the co-creation 
of value with customers...' (Grönroos, 2006b, p. 400). Thus, the firm's task is first and foremost to develop and offer customers such products as can be used in customer processes and practices in a value-creating way; 'the firm is fundamentally a value facilitator' (Grönroos, 2011b, p. 288) and a provider of potential value-in-use, but through direct interactions it can redefine its role to become a value co-creator (Grönroos and Voima, 2013).

\section{Interaction}

According to Lusch and Vargo (2006b), interaction is implicit in S-D logic. Value co-creation is inherently an interactive concept, and interaction is characterized first and foremost by the resource integration perspective taking place through networks (Lusch and Vargo, 2006b; see also Vargo and Akaka, 2009). More recently, the interaction concept has been characterized by S-D logic's close connection with the service science perspective. Maglio et al. $(2009$, p. 400$)$ state interaction is characterized by a series of activities that are jointly undertaken by separate service systems: 'For an interaction to be a service interaction, a proposal must be made by one party to another, agreement must be reached between the parties, and value must be realized by both'. McColl-Kennedy et al. (2012) state that it is through interactions that individuals engage with others in the context of a service network for the purpose of integrating resources. Interaction can take place at multiple levels. By referring to Chandler and Vargo (2011), Akaka et al. (2013, p. 9) argue that at the micro level, "a dyadic interaction (e.g., exchange between a firm and a customer) frames the integration of resources by each actor as well as the value derived and evaluated from that particular encounter"

Service logic approaches interaction as the key factor through which firms can influence the process of value actualization. Therefore, the central construct of marketing 
theory should be interaction, rather than exchange (see Grönroos, 2008a). These interactions are developed to ensure that customers get the value that they originally desired from goods and services. Interaction is also chosen over exchange because it reflects the continuous nature of a customer relationship whereas a product exists only at a given point in time (see Grönroos, 2004). Normatively, firms should then identify and develop new and innovative ways to interact in customers' consumption processes. This is natural in the context of traditional service encounters, but can also be applied in goods marketing, for example, through logistics, order taking, problem diagnosis and so forth (Grönroos and Voima, 2013). In other words, firms should strive to add more resources to the goods themselves to support and facilitate the use of goods or, alternatively, provide customers with additional resources in their value-creating process - goods, service activities, information or access to advice - in a process supportive of value (Grönroos, 2008a).

Furthermore, during interactions, both customer and firm influence each other and are both subjects to (Grönroos and Ravald, 2011; see also Grönroos, 2011a; Grönroos and Voima, 2013), and active participants in, the customer creation of value-in-use (Grönroos, 2009). Consequently, suppliers have opportunities to directly influence customers' valuecreating processes, both in terms of the process and its outcome (Grönroos and Helle, 2010, p. 243): 'The supplier's involvement in its customers' usage processes during interactions with the customers opens up additional opportunities for suppliers to influence customers' value creation'. If no interactions are established, co-creation of value is not possible, and the firm remains merely a value facilitator (Grönroos and Helle, 2010; Grönroos and Ravald, 2011). Importantly, though, interaction in itself is only a platform, an opportunity for the firm to favourably influence the customer's usage and value creation (Grönroos, 2011a), and not a direct antecedent of value co-creation. 


\section{Value co-creation}

Value co-creation is one of the most important concepts of the contemporary service phenomenon and has attracted considerable attention in recent years, and not exclusively from within the marketing discipline. Special journal issues, international conferences and books have been devoted to the issue of exploring the way value is created with instead of for customers.

S-D logic views value as something that is always co-created (Vargo and Lusch, 2008a). The customer is perceived as endogenous to the value creation process, which is why value 'becomes a joint function of the actions of the provider(s) and the consumer(s) but is always determined by the consumer' (Vargo and Lusch, 2006, p. 44). Doing things interactively with the customer is 'a hallmark of S-D logic' (Lusch et al., 2007, p. 12). Thus, S-D logic views both the producer and the consumer as resource integrators that co-create value (Merz et al., 2009). It is a complex process consisting of various resources being integrated from numerous sources (Vargo, 2009). The service provider - whether directly or through a good - is regarded as an element of the customer's value co-creation activities (Vargo and Lusch, 2010b). Value is created with and determined by the user in the consumption process and through use, or what is referred to as value-in-use (see Vargo, 2008) or more recently as value-in-context (Chandler and Vargo, 2011). Vargo (2011a) argues that S-D logic as a whole is fundamentally a value co-creation model that views all actors as resource integrators.

Value co-production for its part can be regarded as optional for customers wishing to engage in the joint production of the core offering with the firm (Lusch and Vargo, 2009). For example, driven by intrinsic motivations or extrinsic rewards, customers can assist firms through taking part in the firm's activities, such as service design or new service development processes (McColl-Kennedy et al., 2012). However, co-creation of value is not 
optional since it occurs as customers use the firm's offering and integrate it with other resources in order to create value with the firm (Lusch and Vargo, 2009). Thus, S-D logic argues that instead of viewing the world in terms of the producer and consumer divide, markets should be determined as actor-to-actor environments (see Lusch and Vargo, 2012). This leads to the definition of value co-creation as 'benefit realized from integration of resources through activities and interactions with collaborators in the customer's service network' (McColl-Kennedy et al., 2012, pp. 1-2; see also Akaka et al., 2012; Vargo and Akaka, 2012; Wieland et al., 2012; Lusch et al., 2010). This definition breaks free of the traditional company-customer conceptualization of value creation and shifts the focus onto all economic actors as value co-creators as they integrate 'market-facing, public, and private resources to create new resources and using these resources to make improvements to their own existence through self-service, and using resources for currency to access additional resources' (Vargo, 2011c, p. 126).

Service logic, on the other hand, perceives value as not always being co-created (e.g. Grönroos, 2008a, p. 305): 'If value is created in customers' value-generating processes and should be understood as value-in-use, and if value-in-exchange for the suppliers is dependent on whether value-in-use is emerging or not, the customers have to be the value creators'. Furthermore, it is the suppliers who acquire opportunities to involve themselves in the customers' value-creating processes, rather than vice versa. Therefore, value - as customer's value-in-use - is created solely by the customer. This is in contrast to S-D logic, where the notion that all actors can co-create value makes the value creation process an all-encompassing event and the concept itself becomes plagued with ontological issues: 'When viewing value creation as an all-encompassing process, co-creation becomes a metaphor - everything is co-creation, everybody co-creates - that does not allow for further analytical developments' (Grönroos and Voima, 2013, p. 137), or it is too simplistic for any 
theoretical development or to enhance practical decision making in any way (Grönroos, 2011b). However, in some cases, and only if interactions between the supplier and customer are established, value (again, as customer's value-in-use) is co-created: 'Co-creation occurs only when two or more parties influence each other or, using service marketing terminology, interact' (Grönroos and Voima, 2013, p. 139, emphasis added). Through engaging in the processes of customers using goods or services, the firm can co-create value with the customer and for the customer (Grönroos, 2008a). Consequently, firms that are able to gain a deep understanding of the customers' practices and processes and devise effective ways of relating to these processes can redefine their roles from being mere facilitators to become value co-creators (Grönroos and Voima, 2013). This clear contradiction between S-D logic and service logic is partly due to using similar concepts for describing the integration and co-creation of a service offering and the evaluation of the value that is uniquely determined by the actor. The importance of using concepts in a concise way is also underlined by Grönroos and Ravald (2011) who argue that in order to understand and manage the creation of customer value, researchers should exercise caution when using expressions such as value creation, and co-creation of value. In addition, crystallizing what kind of value for whom, via what kind of resources, and through what kind of mechanism can also contribute to better understanding of the basic tenets of the service perspectives (see Grönroos, 2011; Saarijärvi et al., 2013).

By referring to Gupta and Lehmann (2005) (as cited in Grönroos and Ravald, 2011), service logic has more recently emphasized the importance of identifying both sides of the value creation equation. This puts emphasis on addressing value and value creation both from the customer's and the firm's perspectives. In that respect, and particularly within an industrial setting, Grönroos and Helle (2010) have recently introduced the concept of mutual value creation and the importance of viewing value as generated through joint productivity 
gains. Mutual value creation is about 'a mutual matching of corresponding practices relevant to the customer's business process, [which means] resources and competencies on both sides are aligned, which enables the supplier to successfully serve the customer in a valuecreating way' (Grönroos and Helle, 2010, p. 573). This allows both parties to address value in financial terms.

\section{Discussion}

Despite the fact that both S-D logic and service logic address some key concepts of the contemporary service phenomenon, (e.g. "goods" and the "value proposition") in a similar way, conceptual conflicts can be identified too (e.g. over "value co-creation" and "interaction"). Furthermore, as illustrated in Figure 1, in terms of some of the key concepts addressed in the previous section, S-D logic and service logic are both contradictory and complementary, insofar as they are in accord on some characteristic of the concept but in conflict over another (e.g. the 'nature of value' and the 'customer'). The service perspectives are indeed both contradictory and complementary. Figure 2 provides a summary of the characteristics of the concepts that are either more complementary or more contradictory (the how) while also revealing the reasons behind them (the why).

\section{"Insert Table 3 approximately here"}

Based on the literature review, it is suggested that the contradictory viewpoints are largely due to four issues. First and most fundamentally, S-D logic and service logic have different backgrounds, which have affected their evolution in both epistemological and empirical terms. For example, S-D logic originates from the historical analysis of economics, political economics and marketing thought (Lusch, 2007, 2006; Vargo and Lusch, 2004a; Vargo and 
Morgan, 2005; see also Lusch and Webster, 2011; Lusch and Vargo, 2009). Vargo (2011b) suggests that what began as an attempt to find convergence, as conceptual and perceptual shifts were occurring in various areas of research (including marketing) has now moved beyond that position. Service logic, in contrast, is at its very core a more empirically based school of thought originating from the Nordic School research tradition (e.g. Gummesson and Grönroos, 2012), and one that has gradually evolved a separate identity. These varying backgrounds, different conceptual starting points and even diverse epistemological origins have naturally also influenced the way S-D logic and service logic interrelate and how they actually address different concepts.

Second, S-D logic and service logic operate at different levels of analysis. S-D logic takes a more holistic view of service by addressing it both on a micro and macro level of analysis. On the one hand it explores service exchange on an actor-to-actor basis, but is also situated on a higher and systemic level of abstraction. Service logic, in turn, is largely focused on a dyadic relationship. Consequently, the different levels of abstraction naturally influence the way in which key concepts, such as value co-creation or interaction, are perceived and used. This, in turn, has led the perspectives toward ontologically differing departure points on the nature of value, for example.

Third, the conceptual confusion around the two perspectives also derives from the difference in use and vague definitions of other service-related concepts such as process, competence and resource. Despite the central role of those concepts in the service perspectives, they have not been explicitly defined or further elaborated. Furthermore, according to Grönroos (2011b), using concepts such as tangible and intangible can be problematic. For example, Grönroos seldom applies the concepts of operant and operand resources that are widely used and emphasized in S-D logic. Although these are not among the key concepts addressed in this study, they still play a major role in defining, approaching 
and elaborating on the service phenomenon itself. In that respect, having even a marginally different understanding of these concepts can easily give rise to a dissonance producing contradictory viewpoints.

Finally, S-D logic and service logic simply apply different emphases in their attempts to address and capture the essence of both the service and marketing phenomena. For example, service logic employs a more customer-oriented approach whereas S-D logic prefers the holistic view of the service phenomenon. Moreover, the former views value mainly in terms of customer value, whereas the latter speaks of value in broader terms. In these cases, the conceptual conflict is not truly fundamental, as the perspectives actually complement each other. Despite not necessarily being completely contradictory, they can easily be misused and misunderstood, leading to friction evident in scholarly discussions (see also Williams, 2012). In that respect, identifying and acknowledging both the contradictory and complementary natures of the conceptual discussion around these perspectives can offer an enhanced level of understanding of contemporary service perspectives. The perspectives differ on what constitutes the very core of marketing as a phenomenon. S-D logic argues that service exchange is the fundamental construct in marketing (Vargo and Lusch, 2008b), which is why marketing should identify and develop the core competences and position them as value propositions that offer potential competitive advantage (Vargo and Lusch, 2004a). Service logic, in turn, views interaction as the fundamental construct in marketing. Marketing should focus on developing and communicating value propositions to customers and facilitating customers' own value creation through resources and interactions (Grönroos, 2008a). This conceptual conflict should not be regarded as merely another difference among several, but as a signal of a more fundamental issue that revolves around the in-depth nature of what eventually constitutes and defines marketing per se. 


\section{Conclusions}

Marketing is the activity, set of institutions, and processes for creating, communicating, delivering, and exchanging offerings that have value for customers, clients, partners, and society at large.

American Marketing Association, definition of marketing (approved October 2007)

When viewed in conjunction with the American Marketing Association's definition, and in particular the stakeholders that are defined as being involved in marketing, service logic is more concerned with customers, clients and partners, whereas S-D logic stresses enlarging the perspective to networks, economies, and nations, that is, to society at large. This evident difference in emphasis helps understand and reflect the contradictions between the perspectives. Operating on a micro, meso or macro level of abstraction bears implications for how the nature of value, value co-creation, or interaction are incorporated, for example. In that respect, when conducting service research that is based on whichever service perspective, it is not only important to be aware of how the various perspectives differ, but also why they differ; what is the fundamental difference in perspective that reveals and explains the contradictory or complementary viewpoint (see Figure 2). Current debate around service provides the mindset and the lens through which contemporary marketing phenomena can be viewed. It does not simply offer tools to understand customers' value creation and how firms can contribute to that, as it also underlines the importance of service at a higher level of analysis. In that respect, understanding the nature, the logic, and the areas of conceptual conflict as well as the parallels between the two well-established service perspectives is of the greatest importance.

To address this important topic, this study aimed to identify the contradictions and complementarities inherent in S-D logic and service logic. Doing so involved conducting a literature review to reveal how the two service perspectives differ in relation to key concepts 
in the contemporary service phenomenon. The aim was not to provide normative suggestions on whether one feature of a particular service perspective was superior to another, but instead to offer a thorough and systematic analysis of the basic conceptual characteristics of both service perspectives. As a result, a set of contradictory and complementary conceptual areas was identified. Furthermore, four issues were discussed that help to address and understand the differences between the service perspectives.

Being aware of these conceptual areas, both contradictory and complementary, helps scholars identify novel theoretical ground for their service research and then develop theoretically consistent approaches in relation to new and interesting service-related research phenomena. Furthermore, such awareness can help researchers to better harness the power of the appropriate logic to suit specific research questions, whether on dyadic service-related relationships, macro-level networks, an organization's ways of engaging in its customers' everyday processes, or the involvement of multiple actors in a resource integration process, for example. In summary, both S-D logic and service logic, when applied appropriately, have great potential to assist the design of interesting and complementary theoretical approaches to better serve contemporary marketing research, regardless of their contradictory stances on some key concepts. In that respect, drawing attention to the most contradictory concepts of the service perspectives, and providing scholarly discussion to promote the reconciliation of the contradictions would best serve the evolution of both service perspectives. Working together to solve these conceptual issues would unlock a vast amount of new conceptual creativity, identify natural points of departures between the service perspectives, and offer genuine synergistic outcomes.

Examination of the study's results reveals three research limitations. First, it should be remembered that S-D logic is regarded as an open and joint effort (e.g. Vargo and Lusch, 2011b). Vargo and Lusch have repeatedly invited scholars to contribute to its development, 
stating that S-D logic is really a work-in-progress; in fact, it is more incomplete than it is complete (Vargo et al., 2010), and 'S-D logic is not so much an academic invention as it is an organic, academic evolution...' (Vargo and Lusch, 2011a, p. 186; see also Vargo, 2008a). S-D logic is a dynamic domain as it is evolving and unfolding rapidly (Vargo, 2008). Therefore, what is suggested in this study as characterizing S-D logic may not necessarily represent it comprehensively, because only the contributions by Vargo and/or Lusch were included. Furthermore, the search in the literature review was limited to peer-reviewed journals. Conference papers (see e.g. Otago Forums 1-3) and books (e.g. Lusch and Vargo, 2006c; Grönroos, 2007) that may contain important conceptual information regarding both S-D logic and service logic were excluded. It should also be noted that the concepts may evolve rapidly and lead to new contradictions and complementarities in terms of both service perspectives. The conceptual discussion is more dynamic than static. Second, the evolution of both S-D logic and service logic are dependent not only on each other but also on the collective research community focusing on different aspects of the evolving service phenomenon. In that respect, addressing only two service perspectives is too limited an approach to provide a comprehensive understanding of the service phenomenon in all its diversity. Thus, it is emphasized that the study focused on two well-established service perspectives, and excluded the exploration of other interesting and useful perspectives such as service science, many-to-many marketing or customer-dominant logic. Third, during the literature review process eight key concepts were chosen for further analysis owing to their central role in both service perspectives. Concepts that have more recently taken shape within the perspectives, such as relationship and market, were not included in the conceptual analysis because there has not yet been as much interaction between S-D logic and service logic over these concepts (e.g. Vargo and Lusch, 2010a; see also Chen and Vargo, 2010; Lusch et al., 2011). For example, S-D logic's recent emphasis on studying markets instead 
of marketing further amplifies the importance of the conceptual developments. In that respect, continuing to explore these issues not only within but also between these perspectives might be considered a suitable future research topic. Finally, it can also be argued whether the two perspectives are comparable in the first place. Do S-D logic and service logic eventually operate at the same ontological level? Nevertheless, given the intensive service-related discussion during the last decade, there is an established need for synthesizing and summarizing the conceptual discussion evolving around these established perspectives, which provided the basic starting point for this study as well.

In the search for a more unifying marketing paradigm, the recent service phenomenon should neither be approached in a superficial manner nor in isolation, but more as part of an attempt to devise and answer questions that define the very nature of the marketing discipline. In this endeavour, identifying the basic building blocks of any perspective and understanding how and why they contradict and/or complement each other is to take a step further on the path to improving marketing research.

\section{References}

Akaka MA, Schau HJ, Vargo SL (2013) The Co-creation of Value-in-cultural-context. Res. Cons. Behav. 15: 265-284.

Akaka MA, Vargo SL (2013) Technology as an operant resource in service (eco)systems. Inf. Syst. E-Bus. Management: 1-18.

Akaka MA, Vargo SL, Lusch RF (2012) An exploration of networks in value cocreation: A service-ecosystems view. Rev. Marketing Res. 9: 13-50.

Akaka MA, Vargo SL, Lusch RF (2013) The Complexity of Context: A Service Ecosystems Approach for International Marketing. J. Int. Marketing 21(4): 1-20. 
Badinelli R, Barile S, Ng I, Polese F, Saviano M, Di Nauta P (2012) Viable service systems and decision making in service management. J. Serv. Management, 23(4): 498-526.

Barile S, Polese F (2010) Linking the viable system and many-to-many network approaches to service-dominant logic and service science. Int. J. Quality Serv. Sciences 2(1): 23-42.

Ballantyne D, Frow P, Varey RJ, Payne A (2011) Value proposition as communication practice: Taking a wider view. Ind. Market. Manag. 40(2): 202-210.

Berry LL, Parasuraman A (1993) Building a new academic field - the case of services marketing. J. Retailing 69(1): 13-60.

Brodie RJ, Saren M, Pels J (2011) Theorizing about the service dominant logic: The bridging role of middle range theory. Marketing Theory 11(1): 75-91.

Chandler JD, Vargo SL (2011) Contextualization and value-in-context: How context frames exchange. Marketing Theory 11(1): 35-49.

Chen HM, Vargo SL (2008) Towards an alternative logic for electronic customer relationship management. Int. J. Bus. Environ. 2(2): 116-132.

Chen HM, Vargo SL (2010) Service-Oriented Challenges for Design Science: Charting the "E-volution". Pac. Asia J. of the Association for Information Systems 2(1): 1-15.

Ehrnrooth H, Grönroos C (2013) The hybrid consumer: exploring hybrid consumption behaviour. Manage. Decis. 51(9): 1793-1820.

Finne Å, Grönroos C (2009) Rethinking marketing communication: From integrated marketing communication to relationship communication. J. Marketing Communications 15(2-3): 179-195.

Fisk RP, Brown SW, Bitner MJ (1993) Tracking the evolution of the services marketing literature. J. Retailing 69(1): 61-103. 
Griffith DA, Lusch RF (2007) Getting marketers to invest in firm-specific capital. J. Marketing 71(1): 129-145.

Grönroos C (2004) The relationship marketing process: Communication, interaction, dialogue, value. J. Bus. Ind. Mark. 19(2): 99-113.

Grönroos C (2005) What can a service logic offer marketing theory. Working Paper Series No. 508, Hanken School of Economics, Helsinki, Finland.

Grönroos C (2006a) Adopting a service logic for marketing. Marketing Theory 6(3): 317333.

Grönroos C (2006b) On defining marketing: Finding a new roadmap for marketing. Marketing Theory 6(4): 395-417.

Grönroos C (2007) In Search of a New Logic for Marketing. Foundations of Contemporary Theory (John Wiley \& Sons, England).

Grönroos C (2008a) Service logic revisited: Who creates value? And who co-creates? Eur. Bus. Rev. 20(4): 298-314.

Grönroos C (2008b) Defining service marketing from a value creation and promise management perspective. J. Chin. Marketing 1(2): 1-15.

Grönroos C (2009) Marketing as promise management: Regaining customer management for marketing. J. Bus. Ind. Mark. 24(5/6): 351-359.

Grönroos C (2011a) A service perspective on business relationships: The value creation, interaction and marketing Interface. Ind. Market. Manag. 40(1): 240-247.

Grönroos C (2011b) Value co-creation in service logic: A critical analysis. Marketing Theory 11(3): 279-301.

Grönroos C (2012) Conceptualising value co-creation: A journey to the 1970 s and back to the future. J. Marketing Management 28(13/14): 1520-1534. 
Grönroos C, Helle P (2010) Adopting a service logic in manufacturing: Conceptual foundation and metrics for mutual value creation. J. Serv. Management 21(5): 564590.

Grönroos C, Helle P (2012) Return on relationships: Conceptual understanding and measurement of mutual gains from relational business engagements. J. Bus. Ind. Mark. 27(5): 344-359.

Grönroos C, Ravald A (2011) Service as business logic: Implications for value creation and marketing. J. Serv. Management 22(1): 5-22.

Grönroos C, Sääksjärvi M, Hellén K, Gummerus J (2007) Love at first sight or a long-term affair? J. Relationship Marketing 6(1): 45-61.

Grönroos C, Voima P (2013) Critical service logic: Making sense of value creation and cocreation. J. Acad. Market. Sci. 41(2): 133-150.

Gummesson E (2008) Quality, service-dominant logic and many-to-many marketing. The TQM J. 20(2): 143-153.

Gummesson E, Grönroos C (2012) The emergence of the new service marketing: Nordic school perspectives. J. Serv. Management 23(4): 479-497.

Gummesson E, Lusch RF, Vargo SL (2010) Transitioning from service management to service-dominant logic: Observations and recommendations. Int. J. Quality Serv. Sciences 2(1): 8-22.

Gutman J (1982) A Means-end chain model based on consumer categorization processes. J. Marketing 46(1) 60-72.

Heinonen K, Strandvik T, Mickelsson KJ, Edvardsson B, Sundström E, Andersson P (2009) Rethinking service companies' business logic: Do we need a customerdominant logic as a guideline. Working Paper Series No. 546, Hanken School of Economics, Helsinki, Finland, 
Heinonen K, Strandvik T, Mickelsson KJ, Edvardsson B, Sundström E, Andersson P (2010) A customer-dominant logic of service. J. Serv. Management 21(4): 531-548.

Heinonen K, Strandvik T, Voima P (2013) Customer dominant value formation in service. Eur. Bus. Rev. 25(2): 104-123.

Holmqvist J, Grönroos C (2012) How does language matter for services? Challenges and propositions for service research. J. Serv. Res. 15(4): 430-442.

Lim SC, Lusch RF (2011) Sales margin and margin capitalization rates: Linking marketing activities to shareholder value. J. Acad. Market. Sci. 39(5): 647-663.

Liu Y, Ram R, Lusch RF, Brusco M (2010) Multicriterion market segmentation: A new model, implementation, and evaluation. Marketing Science 29(5): 880-894.

Lusch RF (2006) The small and long view. J. Macromarketing 26(2): 240-244.

Lusch RF (2007) Marketing's evolving identity: Defining our future. J. Public Policy Mark. 26(2): 261-268.

Lusch RF (2011) Reframing supply chain management: A service-dominant logic perspective. J. Supply Chain Management 47(1): 14-18.

Lusch RF, Brown JR, O'Brien M (2011) Protecting relational assets: A pre and post field study of a horizontal business combination. J. Acad. Market. Sci. 39(2): 175-197.

Lusch RF, Vargo SL (2006a) Service-dominant logic: Reactions, reflections and refinements. Marketing Theory 6(3): 281-288.

Lusch RF, Vargo SL (2006b) Service-dominant logic as a foundation for a general theory. Lusch R, Vargo SL, eds. The service-dominant logic of marketing: Dialog, debate, and directions (ME Sharpe, Armonk, NY), 406-420.

Lusch RF, Vargo SL, eds. (2006c) The service-dominant logic of marketing: Dialog, debate, and directions, (ME Sharpe, Armonk, NY). 
Lusch RF, Vargo SL (2009) Service-dominant logic - A guiding framework for inbound marketing. Marketing Rev. St. Gallen, 6: 6-10.

Lusch RF, Vargo SL (2011) Service-dominant logic: A necessary step. Eur. J. Marketing, 45(7/8): 1298-1309.

Lusch RF, Vargo SL (2012) The forum on markets and marketing (FMM): Advancing service-dominant logic. Marketing Theory 12(2): 193-199.

Lusch RF, Vargo SL, Malter AJ (2006) Marketing as service-exchange: Taking a leadership role in global marketing management. Organ. Dyn. 35(3): 264-278.

Lusch RF, Vargo SL, O'Brien M (2007) Competing through service: Insights from servicedominant logic. J. Retailing, 83(1): 5-18.

Lusch RF, Vargo SL, Tanniru M (2010) Service, value networks and learning. J. Acad. Market. Sci. 38(1): 19-31.

Lusch RF, Vargo SL, Wessels G (2008) Toward a conceptual foundation for service science: Contributions from service-dominant logic. IBM Syst. J. 47(1): 5-14. Löbler H (2011) Position and potential of service-dominant logic - Evaluated in an 'Ism' frame for further development. Marketing Theory 11(1): 51-73.

Maglio PP, Kieliszewski CA, Spohrer JC, eds. (2010) Handbook of Service Science, (Springer, New York).

Maglio PP, Spohrer J (2008) Fundamentals of service science. J. Acad. Market. Sci. 36(1): $18-20$.

Maglio PP, Vargo SL, Caswell N, Spohrer J (2009) The service system is the basic abstraction of service science. Inform. Syst. E-Bus. Management 7(4): 395-406. Mars MM, Bronstein JL, Lusch RF (2012) The value of a metaphor: Organizations and ecosystems. Organ. Dyn. 41(4): 271-280. 
McColl-Kennedy JR, Vargo SL, Dagger TS, Sweeney JC, van Kasteren Y (2012) Health care customer value cocreation practice styles. J. Serv. Res. 15(4): 370-389.

Merz MA, He Y, Vargo SL (2009) The evolving brand logic: A service-dominant logic perspective. J. Acad. Market. Sci. 37(3): 328-344.

Michel S, Vargo SL, Lusch RF (2008) Reconfiguration of the conceptual landscape: A tribute to the service logic of Richard Normann. J. Acad. Market. Sci. 36(1): 152-155.

Peñaloza L, Mish J (2011) The nature and processes of market co-creation in triple bottom line firms: Leveraging insights from consumer culture theory and service dominant logic. Marketing Theory 11(1): 9-34.

Saarijärvi H, Kannan PK, Kuusela H (2013) Value co-creation: Theoretical approaches and practical implications. Eur. Bus. Rev. 25(1): 6-19.

Schmenner RW, Van Wassenhove L, Ketokivi M, Heyl J, Lusch RF (2009) Too much theory, not enough understanding. J. Operations Management 27(6): 339-343.

Spohrer JC, Demirkan H, Krishna V (2011) Service and science. Demirkan H, Spohrer JC, Krishna, V, eds. The Science of Service Systems (Springer, US), 325-358.

Vargo SL (2007a) Paradigms, pluralisms, and peripheries: On the assessment of the S-D Logic. Australas. Marketing J. 15(1): 105-108.

Vargo SL (2007b) On a theory of markets and marketing: From positively normative to normatively positive. Australas. Marketing J. 15(1): 53-60.

Vargo SL (2008) Customer integration and value creation. Paradigmatic traps and perspectives. J. Serv. Res. 11(2): 211-215.

Vargo SL (2009) Toward a transcending conceptualization of relationship: A servicedominant logic perspective. J. Bus. Ind. Mark. 24(5/6): 373-379. 
Vargo SL (2011a) Market systems, stakeholders and value propositions. Toward a service-dominant logic-based theory of the market. Eur. J. Marketing 45(1/2): 217222.

Vargo SL (2011b) On marketing theory and service-dominant logic: Connecting some dots. Marketing Theory 11(1): 3-8.

Vargo SL (2011c) From micro to macro: stakeholders and institutions. J. Macromarketing 31(2): 125-128.

Vargo SL, Akaka MA (2009) Service-dominant logic as a foundation for service science: Clarifications. Serv. Sci. 1(1): 32-41.

Vargo SL, Akaka MA (2012) Value cocreation and service system (re)formation: A service ecosystems view. Serv. Sci. 4(3): 207-217.

Vargo SL, Lusch RF (2004a) Evolving to a new dominant logic for marketing. J. Marketing 68(1): $1-17$.

Vargo SL, Lusch RF (2004b) The four service marketing myths. Remnants of a goodsbased, manufacturing model. J. Serv. Res. 6(4): 324-335.

Vargo SL, Lusch RF (2006) Service-dominant logic: What it is, what is not, what it might be. Lusch RF, Vargo SL, eds. The Service-Dominant Logic of Marketing: Dialog, Debate and Directions (M.E. Sharpe, Armonk, NY), 43-56.

Vargo SL, Lusch RF (2008a) Service-dominant logic: Continuing the evolution. J. Acad. Market. Sci. 36(2): 1-10.

Vargo SL, Lusch RF (2008b) Why service? J. Acad. Market. Sci. 36(1): 25-38.

Vargo SL, Lusch RF (2008c) From goods to service(s): Divergences and convergences of logics. Ind. Market. Manag. 37(3): 254-259. 
Vargo SL, Lusch RF (2010a) Relationship in transition: An introduction to the special issue on relationship and service-dominant logic. J. Bus. Market Management 4(4): 167168.

Vargo SL, Lusch RF (2010b) From repeat patronage to value co-creation in a service ecosystem: A transcending conceptualization of relationship. J. Bus. Market Management 4(4): 169-179.

Vargo SL, Lusch RF (2011a) It's all B2B...And beyond: Toward a systems perspective of the market. Ind. Market. Manag. 40(2): 181-187.

Vargo SL, Lusch RF (2011b) Stepping aside and moving on: A rejoinder to a rejoinder. European J. Marketing 45(7/8): 1319-1321.

Vargo SL, Lusch RF, Akaka MA, Yi H (2010) The service-dominant logic of marketing: A review and assessment. Rev. Marketing Res. 6:125-167.

Vargo SL, Maglio PP, Akaka MA (2008) On value and value co-creation: A service systems and service logic perspective. Eur. Management J. 26(3): 145-152.

Vargo SL, Morgan FW (2005) Services in society and academic thought: An historical analysis. J. Macromarketing 25(1): 42-53.

Vargo SL, Nagao K, He Y, Morgan FW (2007) Satisfiers, dissatisfiers, criticals, and neutrals: A review of their relative effects on customer (dis)satisfaction. Acad. Marketing Sci. Rev. 11(2): 1-19.

Vriens M, ter Hofstede F (2000) Linking attributes, benefits and consumer values. J. Marketing Res. 12(3): 4-10.

Webster FE Jr, Lusch RF (2013) Elevating marketing: marketing is dead! Long live marketing! J. Acad. Market. Sci. 41(4): 389-399. 
Wieland H, Polese F, Vargo SL, Lusch RF (2012) Toward a service (eco)systems perspective on value creation. Int. J. Serv. Sci. Management Eng. Technol. 3(3): 1225.

Williams J (2012) The logical structure of the service-dominant logic of Marketing. Marketing Theory 12(4): 471-483.

Zacharia ZG, Nix NW, Lusch RF (2011) Capabilities that enhance outcomes of an episodic supply chain collaboration. J. Operations Management 29(6): 591-603.

Zacharia ZG, Nix NW, Lusch RF (2009) An analysis of supply chain collaborations and their effect on performance outcomes. J. Bus. Logistics 30(2): 101-123.

Zeng D, Lusch RF (2013) Big Data Analytics: Perspective Shifting from Transactions to Ecosystems. IEEE Intell. Syst. 28(2): 2-5. 
Figure 1.

Rough illustration of the service-related perspectives' inter-linkages combined with some of their key contributions.

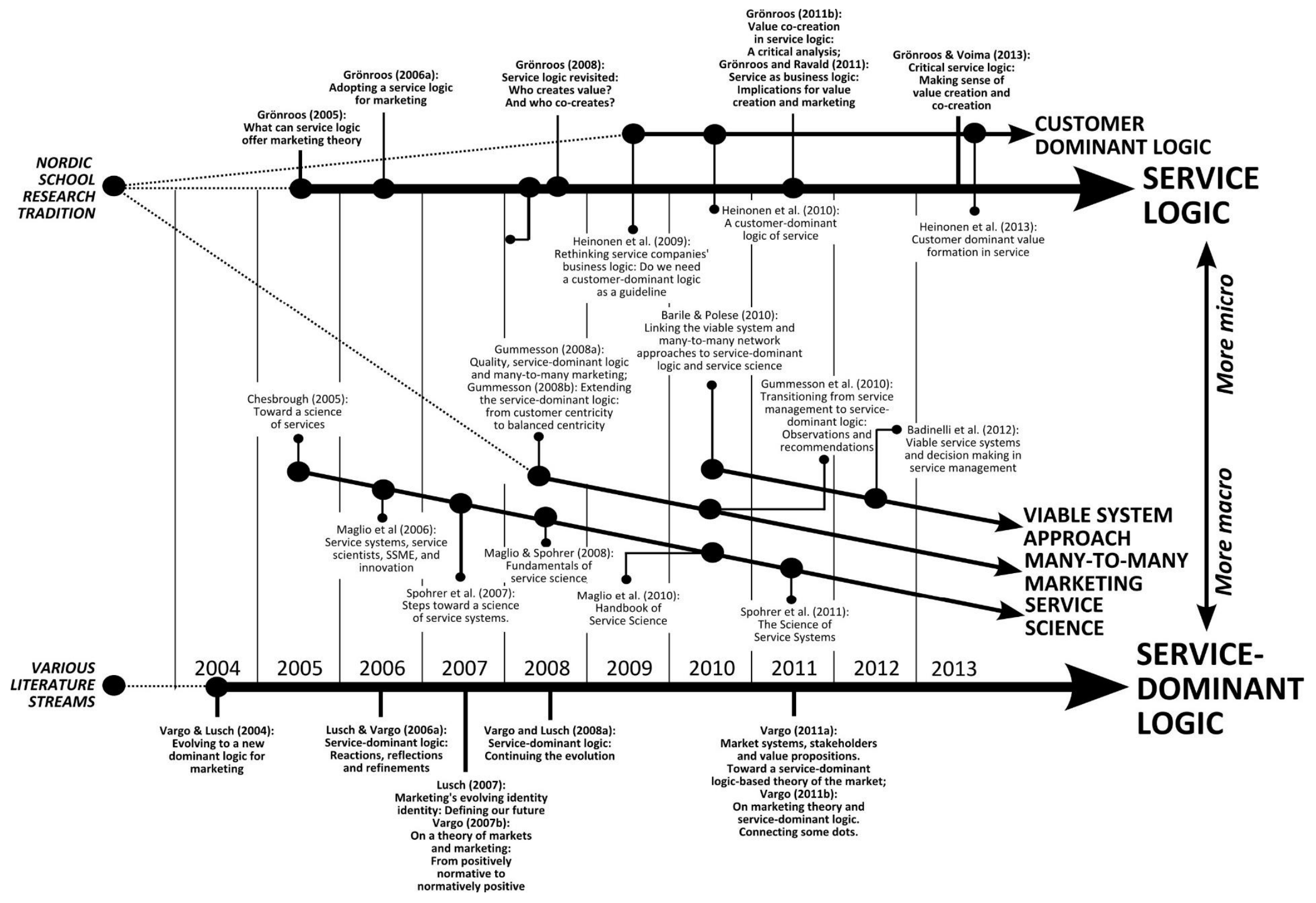


Table 1.

The number of articles included in the literature review (numbers in brackets refer to the articles excluded).

\begin{tabular}{|l|c|c|}
\hline & \multicolumn{2}{|c|}{ Number of articles } \\
\hline Year & S-D logic & Service logic \\
\hline 2004 & 2 & 1 \\
\hline 2005 & 1 & 3 \\
\hline 2006 & 5 & 4 \\
\hline 2007 & $4(2)$ & 2 \\
\hline 2008 & $8(1)$ & $1(1)$ \\
\hline 2009 & $6(1)$ & 1 \\
\hline 2010 & 7 & 3 \\
\hline 2011 & 13 & $3(1)$ \\
\hline 2012 & $6(1)$ & $19(3)$ \\
\hline 2013 & $3(2)$ & \\
\hline Total & $55(7)$ & \\
\hline
\end{tabular}


Table 2.

The articles excluded from the literature review.

\begin{tabular}{|l|l|}
\hline Article & Reason for exclusion \\
\hline $\begin{array}{l}\text { Ehrnrooth \& Grönroos } \\
\text { (2013) }\end{array}$ & Focus on consumer behaviour research \\
\hline $\begin{array}{l}\text { Finne \& Grönroos } \\
\text { 2009) }\end{array}$ & Focus on marketing communications \\
\hline Griffith \& Lusch (2007) & Focus on governance and incentive structures \\
\hline $\begin{array}{l}\text { Holmqvist \& Grönroos } \\
\text { (2012) }\end{array}$ & Focus on the role of language in service encounters \\
\hline Mars et al. (2012) & $\begin{array}{l}\text { Focus on the use of metaphors in the study of } \\
\text { organizations and ecosystems }\end{array}$ \\
\hline Michel et al. (2008) & Editorial, focus on contributions by Richard Normann \\
\hline Vargo et al. (2007) & A review of elements affecting customer satisfaction \\
\hline $\begin{array}{l}\text { Webster \& Lusch } \\
\text { (2013) }\end{array}$ & $\begin{array}{l}\text { Focus on a systems perspective to marketing in } \\
\text { general }\end{array}$ \\
\hline Zacharia et al. (2009) & Focus on capabilities and supply chain collaboration \\
\hline Zeng \& Lusch (2013) & Editorial, focus on big data analytics \\
\hline
\end{tabular}


Table 3. How and why the concept complement/contradict each other

\begin{tabular}{|c|c|c|}
\hline & $\begin{array}{c}\text { How the Concept Complement/ Contradict } \\
\text { Each Other? }\end{array}$ & $\begin{array}{l}\text { Why the Concept Complement/ Contradict } \\
\text { Each Other? }\end{array}$ \\
\hline Goods & $\begin{array}{l}\text { In both perspectives, goods are not embedded with value } \\
\text { and are sub-ordinate to service; goods are only vehicles } \\
\text { for service provision, but cannot deliver service alone - } \\
\text { other resources are needed for the value of the service } \\
\text { to be realized. }\end{array}$ & $\begin{array}{l}\text { Both perspectives are based on service rather than } \\
\text { goods. This fundamental characteristic is shared by both } \\
\text { perspectives and reveals how goods in general are } \\
\text { understood and perceived in value creation. Both } \\
\text { perspectives neglect goods-dominant logic as a general } \\
\text { marketing guideline. }\end{array}$ \\
\hline Service & $\begin{array}{l}\text { Both perspectives identify and acknowledge the process } \\
\text { nature of service in contrast to the output-oriented view } \\
\text { on services. }\end{array}$ & $\begin{array}{l}\text { While there are some difference in the way service is } \\
\text { defined, both perspectives go beyond the traditional IHIP } \\
\text { construct by viewing service from the customer's point of } \\
\text { view and underlining service as superior to goods and } \\
\text { services. }\end{array}$ \\
\hline $\begin{array}{l}\text { Nature of } \\
\text { Value }\end{array}$ & $\begin{array}{l}\text { Both perspectives view value from the beneficiary's point } \\
\text { of view and acknowledge its processual and experiential } \\
\text { nature. }\end{array}$ & $\begin{array}{l}\text { While they prefer using different concepts, such as value- } \\
\text { in-context (S-D logic) and value-in-use (service logic), } \\
\text { their approaches to the basic nature of value per se are } \\
\text { not that contradictory. }\end{array}$ \\
\hline $\begin{array}{l}\text { Value } \\
\text { Proposition }\end{array}$ & $\begin{array}{l}\text { Although there are some contradictions in whether the } \\
\text { firm can only offer value propositions or not, both } \\
\text { perspectives still address value proposition as a firm's } \\
\text { promise that the value-in-use equals the promised value. }\end{array}$ & $\begin{array}{l}\text { Both perspectives adhere the value proposition concept } \\
\text { per se, but disagree on some of its implications for other } \\
\text { service-related concepts (e.g. interaction and value co- } \\
\text { creation). }\end{array}$ \\
\hline Customers & $\begin{array}{l}\text { Both perspectives view the customer as the one who } \\
\text { defines value; however S-D logic perceives customer as } \\
\text { the co-creator of value whereas service logic sees } \\
\text { customer as the sole creator of value. S-D logic prefers } \\
\text { using actor instead of customer. }\end{array}$ & $\begin{array}{l}\text { Both perspectives have adopted the notion that the } \\
\text { customer is an active participant in value creation in } \\
\text { contrast to the customer as passive object. The } \\
\text { contradictions are due to different ontologial approaches } \\
\text { to what ultimately constitutes value creation. }\end{array}$ \\
\hline Firms & $\begin{array}{l}\text { According to S-D logic, firms integrate and transform } \\
\text { different competences into service. Service logic } \\
\text { emphasizes that a firm is fundamentally a facilitator of its } \\
\text { customer's value-creating processes. S-D logic prefers } \\
\text { using actor instead of firm. }\end{array}$ & $\begin{array}{l}\text { Service logic views the role of firms from the customer's } \\
\text { point of view whereas S-D logic adopts and is better } \\
\text { suited to a more macro level of analysis. }\end{array}$ \\
\hline Interaction & $\begin{array}{l}\text { S-D logic views interaction broadly as implicitly } \\
\text { embracing resource integration and as embedded in S-D } \\
\text { logic. Service logic defines interaction more explicitly as } \\
\text { an opportunity for the supplier to affect the customer's } \\
\text { creation of value-in-use. }\end{array}$ & $\begin{array}{l}\text { The perspectives view interaction in different ways due } \\
\text { to S-D logic using the concept in describing interaction on } \\
\text { a more macro level whereas service logic is more focused } \\
\text { on the interaction taking place between the firm and the } \\
\text { customer. }\end{array}$ \\
\hline $\begin{array}{l}\text { Value Co- } \\
\text { Creation }\end{array}$ & $\begin{array}{l}\text { S-D logic views value co-creation as not optional, i.e. } \\
\text { value is always co-created. Service logic argues the } \\
\text { contrary: value is not co-created, it is optional and can } \\
\text { only take place through interactions. }\end{array}$ & $\begin{array}{l}\text { The contradictions are due to different ontological } \\
\text { approaches to what eventually constitutes value creation } \\
\text { and the fact that S-D logic adopts and is better suited to a } \\
\text { more macro level of analysis whereas service logic takes } \\
\text { a more micro perspective. }\end{array}$ \\
\hline
\end{tabular}

